\title{
Current state of labour productivity in the economy of developed countries
}

\author{
Irina Bogatyreva ${ }^{1,{ }^{*}}$, Marina Simonova $^{1}$, and Elena Privorotskaya $^{2}$ \\ ${ }^{1}$ Samara State University of Economics, 141, ul. Sovetskoy Armii, 443090, Samara, Russia \\ ${ }^{2}$ Samara State Technical University, 194, Molodogvardeyskaya ul., 443001, Samara, Russia
}

\begin{abstract}
The article is devoted to the problems of labour productivity increase. It studies trends in labour productivity growth in 12 developed countries and presents a comparative analysis of individual factors that directly affect labour productivity indicators in some European countries as well as the USA and Japan. The article examines and analyzes the reasons for Russia's lagging behind the developed countries of Europe and the USA in terms of labour productivity; the detailed analysis of the level and dynamics of labour productivity in the Russian economy is given. The authors of the article calculated indicators of labour productivity, indicators of the ratio of the average wage growth rates in the economy of the Samara region. Special attention is paid to the study of organizational and socioeconomic factors of increasing labour productivity in conditions of limited financial resources.
\end{abstract}

\section{Introduction}

In the modern Russian economy, there is an obvious need for long-term increase of labour productivity, which will make it possible to provide its competitiveness and stable economic growth. The low level of labour productivity at enterprises influences the general performance of the production system as labour productivity is a criterion of the efficiency of the use of labour in production activities.

The increase of production and reduction of the cost of production and work or services depends on the increase of labour productivity. The level of competitiveness of products (works, services) in sales markets also depends on the state of labour productivity.

Today, low rates of labour productivity increase are the burning problem in all the leading countries of the world. For example, from time to time, the European Parliamentary Network for Technology Assessment publishes the report "Productivity in Europe and the USA" devoted to problems of labour productivity and the experience of their solution in the countries of the European Union and the USA. It examines both common for all countries problems in the field of labour productivity (aging of the population, the need to introduce information technologies into the economy and the system of governance at the state level), as well as specific issues inherent in each specific country. It studies problems of labour productivity common for all countries (aging of the population, the need to introduce

\footnotetext{
* Corresponding author: scorpiony70@mail.ru
} 
information technologies into economy and the system of governance at the state level), as well as specific problems of each particular country.

Studies of the trends of labour productivity increase in 12 developed countries of the world reveal rises and falls in the dynamics of productivity and convergence of processes. There are fluctuations of rises and falls of labour productivity connected with wars, global financial crises, technological shocks which cause decrease of labour productivity in some countries and increase of it in others [1]. Our calculations show that labour productivity in the economies of such developed countries as Ireland, Norway, Germany, and Denmark were increasing systematically during the five-year period of research (Fig. 1), but the growth rates were insignificant (with the exception of Ireland).

The reasons are the dependence of the economy of some countries on the oil and gas industry (Norway), the decline in electronics manufacturing (Finland), the problems in economic and financial policies (Germany), the high level of prices and labour outflow (Denmark).

In the USA, labour productivity was increasing steadily during the period from 2013 to 2016 but in general the increase was only $1.7 \%$.

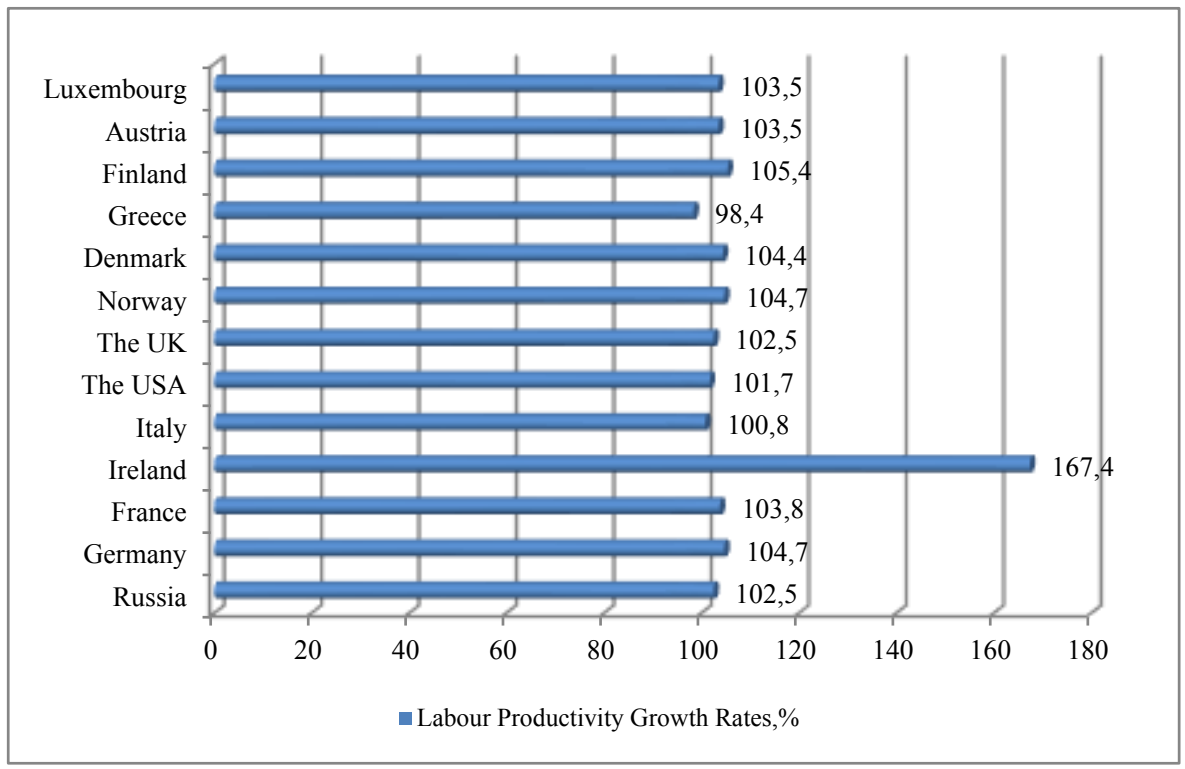

Fig. 1. The Dynamics of Labour Productivity in Russia and Some Foreign Countries during the Period of Five Years (2013-2017), \%.

According to experts, the US economy is moving to a new level: the development and implementation of IT technologies in all the fields of activities can have a positive effect on the increasing of labour productivity and production volumes. But it requires time.

The diversity of the dynamics of labour productivity is also observed in a number of European countries (France, Italy, Austria, The UK, and Luxembourg) where the increase of labour productivity during the above-mentioned period ranges from $0.8 \%$ to $3.8 \%$. First of all it is connected with the decrease of the share of the manufacturing sector in the economy and the small share of the introduction of new technologies in industry (France), the reduction of research and innovation financing (Austria) and inefficient use of resources (The UK).

The negative dynamics of the growth rates of labour productivity is also observed in the economy of Greece. The main reasons for the low labour productivity are the lack of 
innovative activities of enterprises, the insufficient development of new progressive, resource-saving technologies in many sectors of the economy.

The economic and social development of industrialized countries as well as Russia is impossible without the increase of labour productivity. At the legislative level the Russian government is taking measures to solve the problems of accelerating the rates of labour productivity in the country. For example, the government of the Russian Federation proposed a National Programme for Increasing Labour Productivity, the implementation of which should take place in key regions, including the Samara Region, on the basis of scientific principles with a deep economic justification.

The international comparative analysis of individual factors affecting the level and dynamics of labour productivity, and the research of the reasons of the low level of labour productivity in Russia will make it possible to work out a universal plan of measures to increase labour productivity at the Russian enterprises.

\section{Literature review}

Theoretical studies of labour productivity and the factors of its increase have rich historical roots since the beginning of the twentieth century both in Russia [2] and in other countries [3]. However, various issues related to labour productivity are still being discussed. For example, the scientific community is interested in the following questions: is labour productivity a factor of production or its indicator [4]; how to measure labour productivity [5]; what determines the increase of labour productivity [6]; how to assess the impact of socio-economic and organizational factors on the increase of labour productivity of employees of an enterprise.

Very often, in economic literature, the concepts "labour productivity" and "productivity of production system" are interchanged at the level of mesoeconomic and macroeconomic management [7]. This leads to an inadequate interpretation of causes and effects, complicates the search for managerial solutions, reduces a serious economic problem to populist statements and wasteful spending of money [8]. The separation of these concepts is necessary to highlight priority areas in state programmes aimed at the development of the economy, both at the federal and regional levels, concentrating efforts on priorities while maintaining strategic guidelines. At the macroeconomic level, the study of labour productivity is associated with studying regional opportunities, the difference of which depends on many factors.

The subject of a number of scientific studies is the close relationship between regulation of labour and labour productivity [9]. Many scientific papers highlight that labour regulation provides the most complete use of existing reserves of labour productivity and efficient performance [10] while labour standards determine the measure of consumption (tariffs, wages), support economically reasonable correlations between labour productivity increase and wages. Undoubtedly, there is a relationship between the size of wages and labour productivity, which is the subject of a number of scientific studies [11].

\section{Method}

Taking as a basis the definition of labour productivity factors as objectively existing reasons, processes and phenomena, changes in the qualitative and quantitative characteristics of which affect the level and dynamics of labour productivity, we divided the internal for managing labour productivity management tools at an enterprise in relation to a group of factors, for the implementation of which they are intended (Fig. 2). 


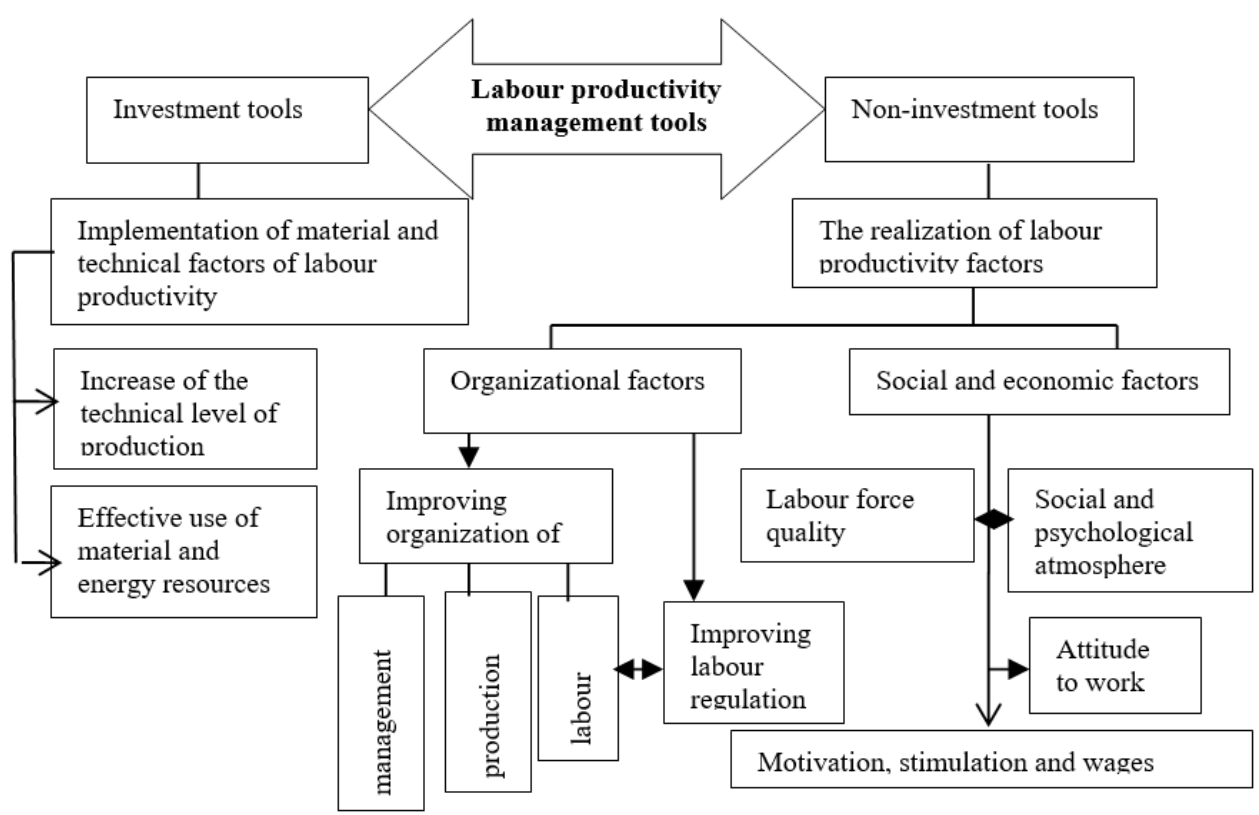

Fig. 2. Labour Productivity Management Tools at an Enterprisem.

This classification focuses on the division of all tools of increasing labour productivity into investment and non-investment ones depending on the degree of financial resources attraction. The investment tools of labour productivity management are understood as a set of economic and managerial means and methods aimed at implementing material and technical factors of labour productivity increase and involving substantial investments in fixed capital.

Material and technical factors of labour productivity are associated with the renovation and modernization of material and technical base of production of an enterprise and the efficiency of using material and energy resources. They create premises for increasing labour productivity as a result of increasing equipment productivity, reducing the cost of producing an item and improving its quality and replacing manual labour with machine labour. Economists consider this group of factors a leading on, determining all other factors. However, all the opportunities for labour productivity increase provided by scientific and technical progress are only potential; their realization of them depends on the person. Many scientists [12] think that the efficiency of using material and technical factors of production depends to a large extent on the organization of labour at an enterprise, and that the expected effect from the use of high-performance equipment can be obtained only if it is rationally combined with workforce labour. Thus, the increase of labour productivity requires not only the increase of the technical level of production and the increase of capital-labour ratio but also the improvement in the use of production fund, which is to a great extent connected with the operation of non-investment tools for managing labour productivity.

Non-investment tools of labour productivity management are a combination of economic and managerial means and methods aimed at activating socio-economic and organizational factors of labour productivity in conditions of limited financial resources. The group of socio-economic factors is aimed at the effective management of the human component of production, and the group of organizational factors is aimed at improving the organization of labour. The realization of both groups of factors makes it possible to increase the productivity of employees without additional financing. 


\section{Practical significance, suggestions and the results of realization, the results of experimental research}

The burning problem of the Russian economy is the unsatisfactory state of labour productivity and a significant lag in the level of labour productivity in comparison with the developed countries. The calculations of the authors of the article showed that in 2016 the level of labour productivity in the economy of the Russian Federation was about $36 \%$ from the corresponding figure of the USA, $37 \%$ from that of Germany, $27 \%$ from that of Luxembourg, and $54 \%$ from that of Japan.

The international comparison of the level of labour productivity per employee and actual work time showed that Russia lags seriously as far as the first indicator is concerned but it overtook other countries in the number of actual working hours. For example, in 2016, the number of actual working hours per average employee in Russia was 1.46 times higher than in Germany, 1.4 times higher than in Norway and Denmark, 1.3 times higher than in France and Luxembourg and 1.1 times higher than in the USA.

The main reason of higher labour productivity in the USA and other developed countries is that the amount of fixed capital per employee, the capital-labor ratio and the energy-labor ratio in are much higher than in Russia [13]. Other factors, such as the availability of research and development aimed at improving production efficiency, the high level of organization and production management, the development, the application of scientifically-based labour standards at enterprises and high qualification of employees, are also of great importance.

The results of calculations of annual labour productivity indexes and the rate of labour productivity increase during the period of six years (calculated as the composition of labour productivity indexes for 2011-2016) allow us to conclude that there has been a steady increase of labour productivity in the Russian economy during the above-mentioned period. The exception is the crisis of 2015. However, the rates of this increase were insignificant and tended to fade out (Table 1).

Table 1. Analysis of the group of factors affecting the level and dynamics of labour productivity in the russian economy for the years 2011-2016.

\begin{tabular}{|c|c|c|c|c|c|c|c|}
\hline \multirow[t]{2}{*}{ Factors } & \multicolumn{7}{|c|}{ Years } \\
\hline & 2011 & 2012 & 2013 & 2014 & 2015 & 2016 & $2016 / 2011 \%$ \\
\hline $\begin{array}{l}\text { Labour Productivity Index , \%; } \\
\text { Labour Productivity Index = Capital-labour Ratio } \\
\text { Change Index* Capital Productivity Change Index }\end{array}$ & 103,7 & 103,5 & 101,8 & 100,7 & 97,8 & 102,1 & 109,8 \\
\hline Capital-labour Ratio Change Index), $\%$ & 103,0 & 103,6 & 100,8 & 113,5 & 96,8 & 100,9 & 119,2 \\
\hline Capital Productivity Change Index, $\%$ & 100,7 & 99,9 & 101,0 & 88,7 & 101,0 & 101,2 & 92,1 \\
\hline Degree of depreciation of fixed assets, $\%$ & 47,9 & 47,7 & 48,2 & 49,4 & 47,7 & 48,1 & 100,4 \\
\hline $\begin{array}{l}\text { The proportion of depreciated fixed assets in } \\
\text { commercial organizations, } \%\end{array}$ & 14,4 & 14,0 & 14,6 & 14,9 & 15,8 & 16,9 & 117,4 \\
\hline The rate of renovation of fixed assets, $\%$ & 4,6 & 4,8 & 4,6 & 4,3 & 3,9 & 3,7 & 80,4 \\
\hline $\begin{array}{l}\text { The share of investments in fixed assets in the GDP, } \\
\%\end{array}$ & 20,7 & 20,9 & 21,2 & 20,5 & 19,6 & 20,4 & 98,6 \\
\hline $\begin{array}{l}\text { The share of added value of high-tech and } \\
\text { knowledge-intensive activities in the GDP of the } \\
\text { Russian Federation, } \%\end{array}$ & 19,7 & 20,3 & 21,1 & 21,8 & 21,3 & 21,6 & 109,6 \\
\hline Share of organizations introducing innovations, $\%$ & 10,4 & 10,3 & 10,1 & 9,9 & 9,3 & 8,4 & 80,8 \\
\hline $\begin{array}{l}\text { Expenditures on research and development, } \% \text { of the } \\
\text { GDP in the Russian Federation in general }\end{array}$ & 1,01 & 1,03 & 1,03 & 1,07 & 1,10 & 1,10 & 108,9 \\
\hline $\begin{array}{l}\text { Expenditures on civil science from the federal } \\
\text { budget, \% to the GDP }\end{array}$ & 0,52 & 0,52 & 0,58 & 0,55 & 0,53 & 0,47 & 90,4 \\
\hline $\begin{array}{l}\text { The coefficient of invention activities (the number } \\
\text { of domestic patent applications for inventions in } \\
\text { Russia, per } 10 \text { thousand people) }\end{array}$ & 1,85 & 2,00 & 2,00 & 1,65 & 2,00 & 1,83 & 98,9 \\
\hline
\end{tabular}


After reaching the minimum values in 2015 , labour productivity resumed increase, exceeding the pre-crisis figures for the years 2013-2014 for $0.3-1.4$.

In general, during six years labour productivity in the economy increased only 1.09 times, while in Germany and Japan labour productivity increased 1.2 times and 1.15 times in the USA during the same period.

The task of increasing labour productivity can be solved by activating material, socioeconomic and organizational factors. In particular, the renovation and modernization of the technical base of production at Russian enterprises, the increased investment activity of economic entities and the creative activity of employees have a direct impact on the positive dynamics of labour productivity increase. Special attention should be paid to the financing of research and development, which should be significantly increased.

The data on the factors of labour productivity given in Table 1 indicate their poor condition. It is not a secret that labour productivity increases not only due to the increase of the technical level of production (capital-labour ratio) but also due to the improvement of the use of production assets (capital productivity).

During the period of six years from 2011 to 2016, the capital-labour ratio in the country's economy increased by $19.2 \%$, while capital productivity decreased by $7.9 \%$. As a result during six years the increase of labour productivity reached 9.8\% $(119.2 * 92.1 / 100$ - 100). The low level of capital productivity indicates the unsatisfactory state of fixed assets. This is evidenced The high degree of depreciation of fixed assets $(48.1 \%)$, low rates of their renewal (3.7\%) and minor investments in fixed assets $(20.4 \%)$ also confirm this [14].

Low innovation activity of enterprises and organizations. In 2016, only $8.4 \%$ of Russian organizations introduced technological, organizational and marketing innovations. Most innovations are related to the development and introduction of new technologies into production, the replacement and modernization of equipment, the transition to production automation. According to statistics, the share of such organizations in 2016 was $7.3 \%$.

However, the introduction of technological innovation requires additional investments in fixed assets. Not all Russian enterprises have the financial ability to update and modernize the material and technical base of production. But many managers forget that they have "non-investment", low-cost tools, the effect of the implementation of which makes it possible to increase the labour productivity of employees without attracting additional finance in a short time. Among these tools is the activation of socio-economic and organizational factors of labour productivity. The action of the first group of factors is aimed at the effective management of the human component of production and that of the second is aimed at the improving of the organization of labor. Scientific and technological progress provides great opportunities for labour productivity increase which in practice can only be realized only by people.

Statistical data show that the share of organizations implementing organizational and marketing innovations is very little (2.4\% and $1.4 \%$, respectively).

The Russian Federation lags behind European countries, the United States and Japan in terms of the volume of financing of scientific and technological research and technological development, ensuring quality development and improvement of production efficiency. The costs of this research and development in the USA and Germany are 2.5 times higher than that of the Russian companies, and in Japan they are about 3 times higher (Table 2).

These data must be read not only in absolute terms, but also in qualitative terms, in comparable prices, in terms of purchasing power and other equally important factors, when these figures do not fully reflect the real situation in production.

The allocations for research and development $(R \& D)$ from the state budget in Germany and Japan are two times higher than in Russia and in the USA they are 8.8 times higher than in Russia (Fig. 3). 
Table 2. The dynamics of changes in domestic spending on research and development from GDP in developed countries, $\%$.

\begin{tabular}{|c|c|c|c|c|c|c|c|}
\hline \multirow{2}{*}{ Country } & \multicolumn{6}{|c|}{ Years } & \multirow{2}{*}{$\begin{array}{l}2016 \% \\
\text { to } 2011 \\
\end{array}$} \\
\hline & 2011 & 2012 & 2013 & 2014 & 2015 & 2016 & \\
\hline Japan & 3,24 & 3,21 & 3,31 & 3,4 & 3,28 & 3,14 & 96,9 \\
\hline Germany & 2,8 & 2,87 & 2,82 & 2,87 & 2,92 & 2,94 & 105 \\
\hline The USA & 2,7 & 2,69 & 2,72 & 2,73 & 2,74 & 2,74 & 101,5 \\
\hline France & 2,19 & 2,23 & 2,24 & 2,28 & 2,27 & 2,25 & 102,7 \\
\hline The Netherlands & 1,9 & 1,94 & 1,95 & 2,00 & 2,00 & 2,03 & 106,8 \\
\hline Norway & 1,63 & 1,62 & 1,65 & 1,71 & 1,93 & 2,04 & 125,1 \\
\hline Russia & 1,01 & 1,03 & 1,03 & 1,07 & 1,10 & 1,10 & 108,9 \\
\hline
\end{tabular}

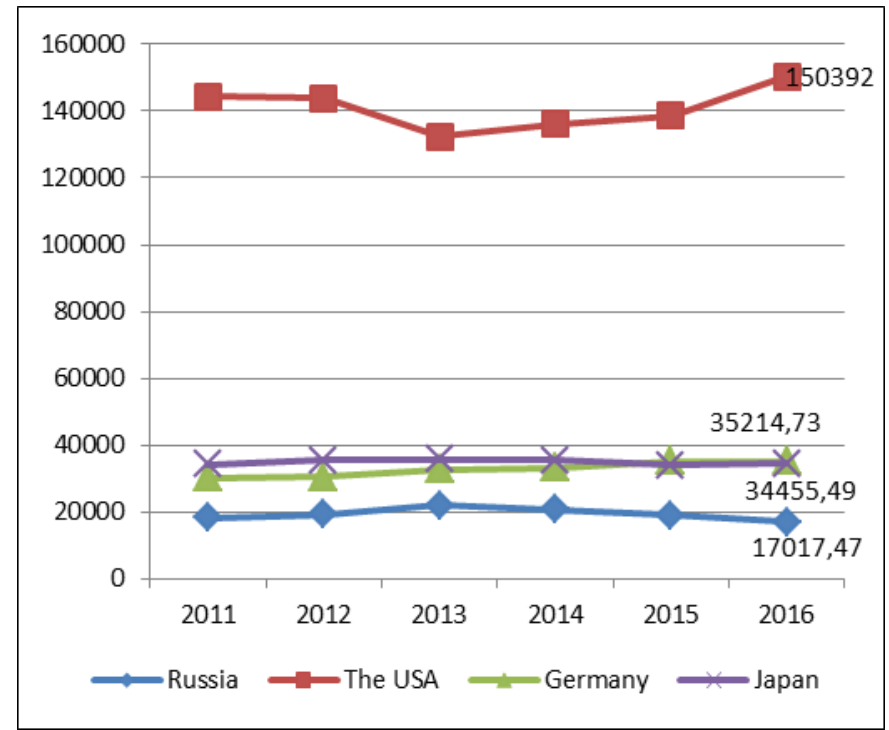

Fig. 3. The Dynamics of State Budget Expenditures on R \& D in the Russian Federation and the Developed Countries of the World, mln. dollars.

The initiatives of individual employees, their ambition for constant innovations in the field of their professional activities, ensuring the increase of labour productivity and improvement of the quality of work or products, significantly affect the level of innovative activity of organizations.

In Russia, the coefficient of inventive activity, according to Rosstat, is much lower than in other countries. In Russia the number of applications for inventions in 2016 was 1.83 per 10,000 people while in Germany it was 6 , in the USA -8 and in Japan - 26. These data show not only the complexity of the task of increasing labour productivity in the Russian economy but also the available reserves and possible ways of solving it.

Special attention should be paid by the state and employers to the analysis of the indicators of the ratio of increase rates of average wages: outpace coefficient and salary intensity coefficient. This ratio affects the change in the cost of products, works and services. The higher the share of wage costs in the cost structure, the greater this impact. It is possible to reduce the cost of production if labour productivity grows faster than average wage. Otherwise, the cost of production will increase.

The long-term development strategy of the Russian economy sets high parameters for the economic growth rate of at least 5\% of the GDP annually, which to a large extent depends on the growth rates of labour productivity. The existing potential is not utilized to full 
extent; in recent years there has been a decline in many spheres of the economy. For example, the growth rate of labour productivity on average does not exceed $1.3 \%$ per year, which is an extremely low figure that cannot provide the necessary economic growth. The task of a substantial increase of the growth rate of labour productivity has a number of limitations, including financial ones. Lack of financial resources slows down the renewal of fixed assets of production which is the main engine of labour productivity growth. The results of the analysis of domestic and foreign experience on the topic of the research revealed a significant lag of Russia in comparison with the developed countries in a number of important parameters affecting productivity, such as financing scientific and technological research and technological developments, coefficients of inventive activity, etc. Today there is an objective need to systematize tools of performance management and distinguish those that can be applied in the short term and with minimal costs due to the internal reserves.

\section{Conclusions}

In conditions of limited financial resources, the research and finding of low-cost tools for managing labour productivity becomes the top priority task of the Russian economy. Labour productivity increase can be achieved not only by technical and technological innovations, but also by other, low-cost but equally important tools that can have a significant effect even with the use of existing equipment. Low labour productivity at many Russian enterprises is stipulated not only by the high degree of equipment depreciation but to a large extent by the high level of losses of various kinds, including defects, equipment downtime, poor product quality, inefficient organization of work, low motivation of personnel and other factors that determine the production culture. If these factors are not taken into consideration, labour productivity even with the use of new equipment may be significantly lower than with the use of the old one. One of the main methods of increasing labour productivity is technological renovation of production, when, due to mechanization and automation, the number of personnel and production time are reduced while the product quality and competitiveness are increased. However, in most cases there are investment and other limitations of the possibilities of rapid investments while there is a need in production efficiency increase. At the same time, the awareness of enterprises about the possibilities of increasing labour productivity by using non-investment methods in the short term remains extremely low, and the possibilities of implementation of such reforms by enterprises is rather low too because of the burden of current duties and the lack of specialists with necessary qualifications.

\section{References}

1. G. Lanza, J. Stoll, N. Stricker, S. Peters, C. Lorenz, Procedia CIRP 7, 31-36 (2013)

2. E.A. Barykin, Reforms and Law 1, 29-43 (2015)

3. D.S. Sink, Productivity Management: Planning, Measuring and Estimating, Control and Increase (Progress, Moscow, 1989)

4. T.O. Seleznyova, Scientific Discussion: Questions of Economics and Management 5, 91-101 (2015)

5. N.N. Shash, A.I. Borodin, Scientific Notes of Petrozavodsk State University 3-1(148), 96-101 (2015)

6. C. Syverson, Journal of Economic Literature 49(2), 326-365 (2011)

7. I.V. Chistnikova, M.V. Antonova, European Science 4(5), 18-20 (2015) 
8. E. Prescott, E. McGrattan, The Labor Productivity Puzzle (Meeting Papers, 2012)

9. V.A. Schekoldin, I.V. Bogatyreva, L.A. Ilyukhina, V.M. Kornev, Helix 8(5), 36153628 (2018)

10. V.A. Schekoldin, I.V. Bogatyreva, L.A. Ilyukhina, Economic Sciences 9(154), 21-28 (2017)

11. R. Riley, Labour Economics 44, 27-50 (2017)

12. V.A. Vaisburd, Labour Economics. Second Edition (Omega-L, Moscow, 2012)

13. V.A. Vaisburd, M.V. Simonova, I.V. Bogatyreva, E.G. Vanina, E.P. Zheleznikova, International Journal of Economics and Financial Issues 6(S5), 157-165 (2016)

14. M.V. Simonova, I.V. Bogatyreva, Bulletin of Voronezh State University. Series: Economics and Management 3, 95 (2016) 